\title{
Comparative study of cherry varieties used in intense culture
}

\author{
Vaszily, B. \\ Centre for Agricultural Sciences and Engineering, University of Debrecen \\ 138 Böszörményi St., 4032 Debrecen, Hungary
}

\begin{abstract}
Summary: Research in sweet cherry production is intensely stimulated worldwide. The programs started also in Hungary to develop technologies and to find suitable varieties for the purpose of intense cultivation. It means that dimension of crowns should be smaller, with higher number of plants per hectare. Understocks, which let grow the trees slower, are scarce in this species. On the one hand, the braking effect of the respective stocks is insufficient, they get old pretty soon, loose ramification, yield too small fruits and do not comply with the aims of intense cultivation. Experiences prove the necessity of stocks for intense culture, which are vital, growing, easily regenerating, and freely branching. Mahaleb (Prunus mahaleb), a strong growing stock, is still suitable. Further improvement is expected from the contribution of technological elements and the choice of variety. In the present paper, a 9-year old plantation is shown with trees trained to (slender) spindle, and the yield and fruit quality of the year 2009 has been analysed with 6 varieties involved.
\end{abstract}

Key words: cherry varieties, sweet cherry

\section{Introduction}

An obligate condition of reorganising Hungarian fruit production is to increase intensity of the technology. The surface of the tree crown should be exposed to direct sunshine in order to receive good and uniform fruit quality. Intensification meets several obstacles. In several countries, a search for dwarfing stocks is attempted (Hrotkó, 2000). In Hungary, no dwarfing stocks could be found for that purpose.

Stocks of moderate vigour could not trained with radical pruning to stimulate regeneration of fruiting shoots. This syndrome of declining fruiting shoots is associated with small fruit size, a tendency of senescence and reduced vitality (Bujdosó, 2004). According to our experience, we have to keep to the strong growing stocks, e.g. Prunus mahaleb has still good chances in intense technologies. With vigorous stocks, growing may braked by various phytotechnical interventions (e.g. by timing and intensity of pruning as well as by root pruning, etc.). The respective research has been attempted in several countries of the world. In Germany, Zahn developed the training to slender spindle (Zahn, 1986, 1990). The spindle allows an adequate regeneration on the main axis by growing shoots.

Green pruning is an essential moment, as the outer periphery parts are thinned. By this way, the shoots starting from the inner parts receive sufficient light and develop bouquets of flowers.

For the intense growing technology, the properties of the respective variety are decisive, especially its growing intensity, branching habit, disease susceptibility; moreover, the quantity and quality of developing fruit bearing shoots. There are considerable differences between the varieties regarding the characters mentioned, i.e. suitability to intense cultivation (Király \& Gonda, 2004; Király et al., 2005, Gonda et al., 2007; Holb, 2009).

\section{Material and methods}

The experiments have been performed at DebrecenPallag, on the Experimental Farm of Horticulture and Regional Research Centre.

Cherry trees have been planted in the spring of 2000 on Mahaleb stocks, $4 \times 1 \mathrm{~m}$ distance. Trees have been trained to slender spindle (super-spindle). The height of the crowns was $2.5 \mathrm{~m}$, the diameter $1 \mathrm{~m}$. The trees developed a dominant main axis with spirally set lateral branches of 1-4 year old age.

Our assortment of varieties disposed of nearly 60 sweet cherry varieties, but only current varieties represented on the market were eligible, therefore 6 of them are chosen ('Linda', 'Axel', 'Stella', 'Germersdorfi 3', 'Sunburst', 'Van').

The productivity has been determined by counts of the fruiting parts of different age and distributed on the crown. Depending on the age of respective parts, the mean number of flowers, and later fruits, per bouquet was referred to the length of the respective branch.

The dimensions of the fruits (d1, d2 and height) as well as the stem length were measured by a slide-gauge, and weighed by a balance. 


\section{Results}

The fruit charges of different parts being of various age are presented in Table 1. The following statements are made:

On the two-year-old parts, the number of bouquets was conspicuous in every variety. As generally recognised, those are the most precious fruiting parts of cherries. In 'Germersdorfi 3' and 'Stella' varieties, there were many single buds, which means many points of growth. On the three-year-old parts, the varieties 'Linda', 'Axel', 'Sunburst' and 'Van' developed the same number of bouquets, like on the two-year-old parts. 'Germersdorfi 3' produced the half of that quantity, 'Stella' one third of that observed on the younger parts. In spite of that, 'Germersdorfi 3' and 'Axel' proved to be rather productive even on the four-year-old parts. In the case of 'Linda', the four-year-old parts became partly bald.

The difference between varieties is obvious as shown in Figure 1, where we see the mean number of flowers per bouquet according to the age of the part.

It is interesting that the three-year-old bouquets bear the most number of flowers with the exception of the varieties

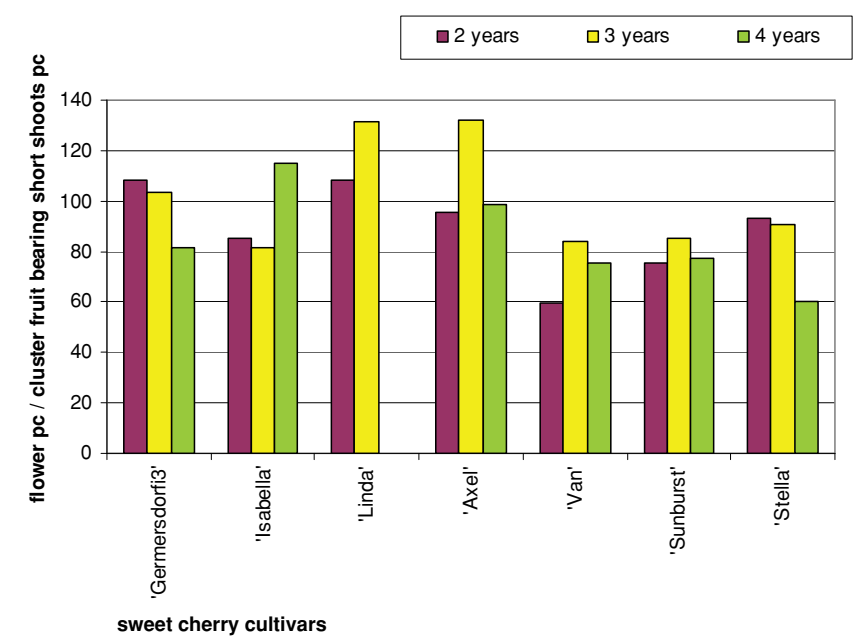

Figure 1: Number of flowers on the fruiting bouquets of sweet cherry varieties (\%) (Debrecen-Pallag, 2009)
'Germersdorfi 3' and 'Stella'. At the same time, the varieties mentioned bear more flowers on the two-year-old bouquets than the rest of varieties. However, a general decline of number of flowers per bouquet was observed. From this point of view, the variety 'Linda' in unique as observed on Table 1, where on the four-year-old parts no fruiting buds are at all.

The number of flowers per branch current meters is shown in Figure 2. The differences between varieties and age of the branch were conspicuous. Extraordinary high number of flowers was found in the one-year-old branches of variety 'Linda', and this variety shows increasing of the number of flowers with the growing age of the branch. However, the same variety became bald on the four-year-old branches.

In varieties 'Axel' and 'Stella', the decline of the branches with progressing age is experienced. On the fouryear-old parts, almost all varieties produced the less number of flowers. Most peculiar was the case of 'Van' and 'Germersdorfi 3'; the former produced high means of flower number on the 2-3 year old parts, the latter on the secondand fourth-year-old parts.

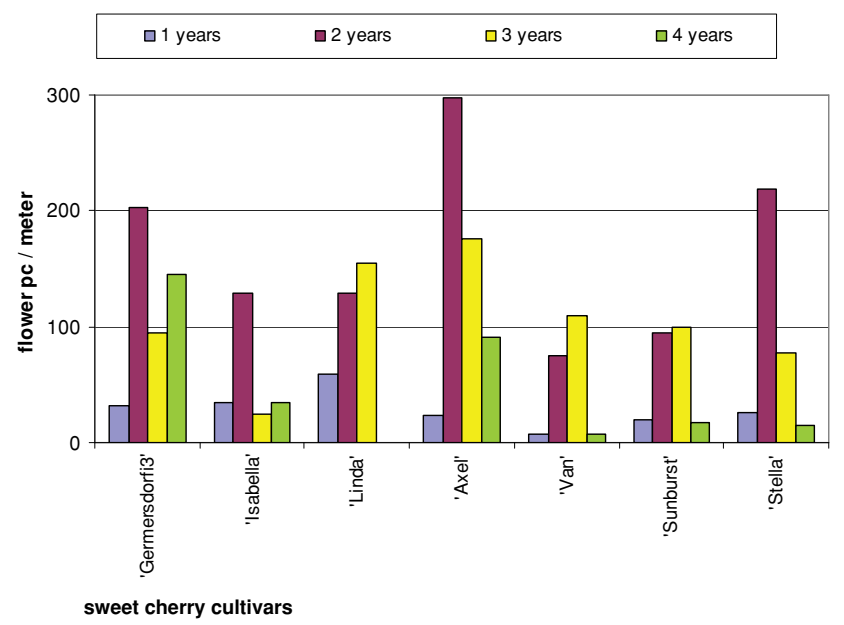

Figure 2: Number of flowers on fruiting parts of different age, one to fouryear-old, in sweet cherry cultivars (Debrecen-Pallag, 2009)

Table 1. Fertility of different fruiting parts of different age in cherry varieties (Debrecen-Pallag, 2009)

\begin{tabular}{|c|c|c|c|c|c|c|}
\hline & $\begin{array}{l}\text { Single buds } \\
\text { bud } / \mathrm{m}\end{array}$ & $\begin{array}{l}\text { Bouquet of buds } \\
\text { bud/m }\end{array}$ & $\begin{array}{l}\text { Single buds } \\
\text { bud } / \mathrm{m}\end{array}$ & $\begin{array}{l}\text { Bouquet of buds } \\
\text { bud } / \mathrm{m}\end{array}$ & $\begin{array}{l}\text { Single buds } \\
\text { bud } / \mathrm{m}\end{array}$ & $\begin{array}{l}\text { Bouquet of buds } \\
\text { bud } / \mathrm{m}\end{array}$ \\
\hline \multicolumn{7}{|c|}{ Age (years) of fruiting parts } \\
\hline Cherry varieties & 2 & 3 & 4 & & & \\
\hline 'Germersdorfi3' & 3.86 & 18.71 & 2.2 & 9.1 & 1.37 & 17.81 \\
\hline 'Linda' & 0.48 & 11.87 & 0 & 11.76 & 0 & 0 \\
\hline 'Axel' & 0 & 31.25 & 4.22 & 13.25 & 1.72 & 9.19 \\
\hline 'Van' & 1.58 & 12.63 & 0.33 & 13.05 & 2.13 & 1.06 \\
\hline 'Sunburst' & 2.62 & 12.42 & 0 & 11.66 & 0 & 2.27 \\
\hline 'Stella' & 3.82 & 23.47 & 3.96 & 8.49 & 0 & 2.44 \\
\hline
\end{tabular}




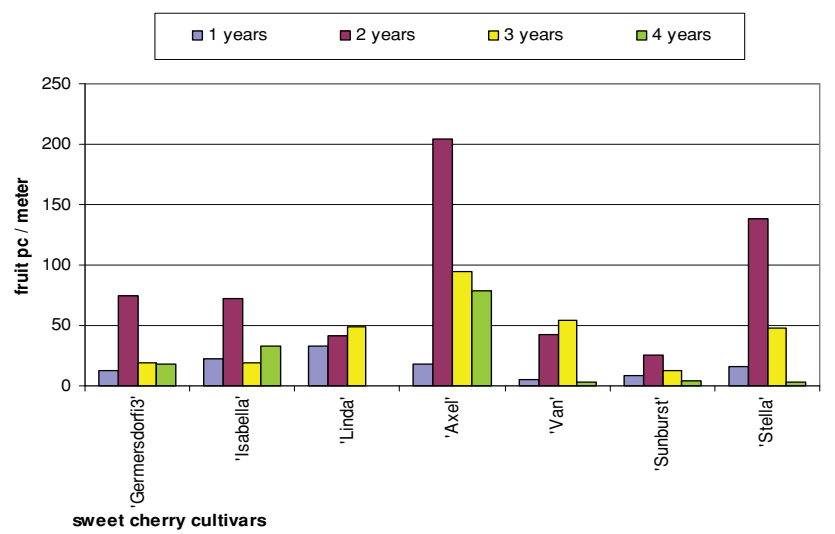

Figure 3: Number of fruits per current meter on the branches of different age in cherry varieties (Debrecen-Pallag, 2009)

Figure 3 shows the number of fruits set per current meter on the branches, whereas fruits set per flowers (\%) by Figure 4 on fruiting parts of different age in cherry varieties.

The most productive fruiting parts of the variety 'Germersdorfi 3' are found on the branches of 1-2 years old. In spite of that, the rate of fruit set was relatively low (Figure 4). In variety 'Linda', the fruiting set capacity is declining, whereas the number of flowers showed an opposite tendency. Fruit set of variety 'Van' was largely mediocre on fruiting parts of different age, whereas 'Sunburst' set fruit at a low rate.

Outstanding rates of fruit set were experienced in varieties 'Axel' and 'Stella', which produced well even at the four-year old parts.

The mean fruit volume of fruits depended mainly on the fruit charge of the plant (Figure 5). Varieties 'Linda' and 'Germersdorfi 3' are renown for their very large fruit; however, we concluded that the fruit size was rather due to the low rate of fruit set as proved by Figure 4. The variety 'Axel' produced the lowest fruit size, below $6 \mathrm{~g}$, because it produced the highest rates of fruit set.

Subsequently, the parameters of fruits and the length of stems are presented in Figure 6. With the fruit volume are changing the dimensions ( $\mathrm{d} 1, \mathrm{~d} 2$ and $\mathrm{M})$. 'Germersdorfi 3' and 'Linda' produced diameters of $27 \mathrm{~mm}$. 'Axel' being the

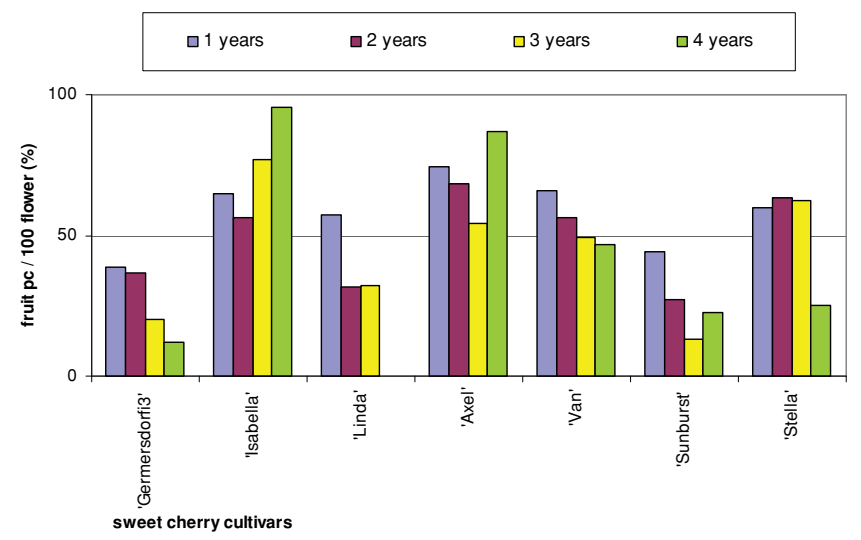

Figure 4: Fruits set per flowers (K\%) on fruiting parts of different age in cherry varieties (Debrecen-Pallag, 2009)

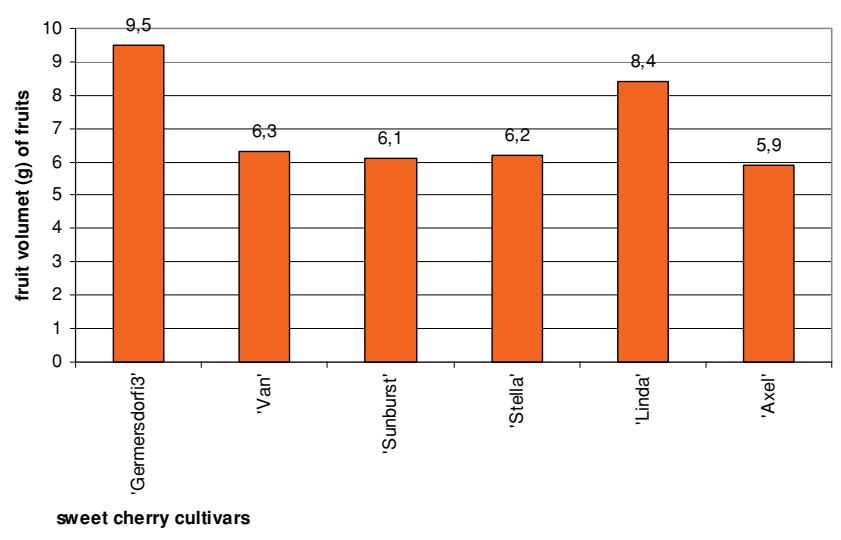

Figure 5: Fruit volume (g) of fruits in sweet cherry varieties (DebrecenPallag, 2009)

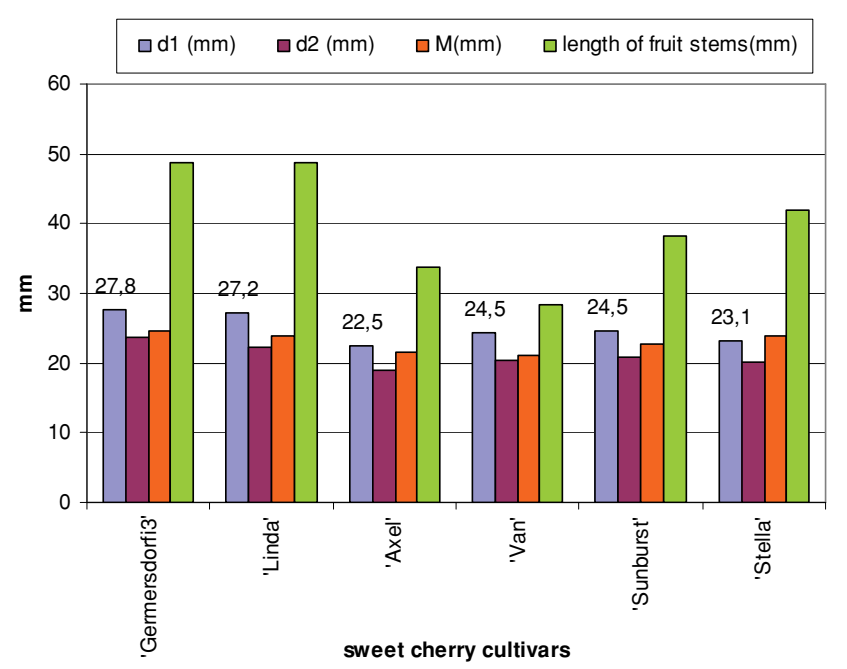

Figure 6: Dimensions of cherry fruits and the length of fruit stems in the varieties examined (Debrecen-Pallag, 2009)

smallest with $24 \mathrm{~mm}$ because of the high rate of fruit set in that very case.

The longest fruit stems characterise the varieties 'Germersdorfi 3' and 'Linda'. The long stem is a disadvantage for mechanical harvesting.

In Table 2, the performance of cherry trees are characterised according to their yield in 2009, fruit characters born on trees trained to (slender) spindle. The yields were calculated for hectares taking 2500 trees/ha planting density.

Table 2. The performance (yields and fruit characters) of sweet cherry varieties (Debrecen-Pallag, 2009)

\begin{tabular}{|l|c|c|c|c|}
\hline & $\mathrm{kg} / \mathrm{tree}$ & $\mathrm{t} / \mathrm{ha}$ & $\begin{array}{c}\text { Diameter } \\
\mathrm{d} 1\end{array}$ & $\begin{array}{c}\text { Volume } \\
(\mathrm{g})\end{array}$ \\
\hline 'Germersdorfi3' & 3.9 & 9.8 & 27.8 & 9.5 \\
\hline 'Sunburst' & 4.7 & 11.7 & 24.5 & 6.1 \\
\hline 'Van' & 7.6 & 19.1 & 24.5 & 6.3 \\
\hline 'Stella' & 10.7 & 26.8 & 23.1 & 6.2 \\
\hline 'Linda' & 10.9 & 27.3 & 27.2 & 8.4 \\
\hline 'Axel' & 11.3 & 28.4 & 22.5 & 5.9 \\
\hline
\end{tabular}


'Axel' produced the smallest fruit because of its tendency of copious yield and fruit set in the year examined. Fruit size is, however, an important component of quality. Low yield and large fruit is found to be associated in the variety 'Germersdorfi 3'.

The varieties, except 'Germersdori 3' produced acceptable yields, which should be more than 10 t/ha. Especially, 'Linda' should be praised because its high yield (nearly $30 \mathrm{t} / \mathrm{ha}$ ) was associated with large fruits.

\section{Conclusions}

Our examinations corroborated the statement that there are substantial differences between sweet cherry varieties regarding their performance in yielding, fruiting structures and fruit quality. The varieties performed fairly well as trained to (slender) spindle crowns except' Germersdorfi 3', which yielded $4 \mathrm{~kg} /$ tree only because of low rate of fruit set. It should be remembered that earlier, in years without frost damage, some 6-9 kg/tree has been harvested.

It could be stated that with yields produced in plantations with a $4 \times 1 \mathrm{~m}$ planting design, very high yields could be produced on spindle trees. For that purpose, the building up and regeneration of fruiting structures as variety characters should be thoroughly examined and exploited. Differences between varieties are conspicuous; therefore a proper pruning policy should be developed for each variety. Chances ought to be given of the particular fruiting structures, which proved to be optimal for the respective variety. The so called "rotation-pruning", which refers to the necessity of pruning at different dates of the fruiting structures of different age, may prevent or delay the imminent processes of senescence.

As demonstrated, the braches of the variety 'Linda' become bald at an age of 4 years, that means, for this variety the partial rejuvenation of the fruiting parts is actual on the 3 -year-old branches. On the contrary, other varieties as 'Axel' and 'Van' are fully fertile in their 4-year-old structures.
Further research is necessary to compare the performance of fruiting structures in different varieties, and the effects of age on the fruit characters especially fruit size and quality.

The increasing intensity of growing techniques should be coupled with producing higher quality, which should be realised with pruning policies adapted to the specific variety and growing techniques as well.

\section{References}

Bujdosó, G. (2004): Gondoljuk át a növekedésmérséklő cseresznyealanyok használatát. Gyakorlati Agrofórum, 15 (2): 43-45.

Bujdosó, G. \& Hrotkó K. (2003): HrA cseresznye és a meggy növekedése és termőre fordulása növekedést mérséklő alanyokon. Kertgazdaság, 35 (3): 3-10.

Gonda, I., (2003): Metszést kiegészítő eljárások. (In: Papp J. (szerk): Gyümölcstermesztési alapismeretek.) Mezőgazda Kiadó, Budapest, 300-305.

Gonda, I., Király, K. \& Holb, I.J. (2007): Examination of growth of cherry cultivars adapted to intensive production. Acta Hort., 732: 429-434.

Holb, I.J. (2009): Some biological features of cherry leaf spot (Blumeriella jaapii) with special reference to cultivar susceptibility. International Journal of Horticultural Science, 15 (1-2): 91-94.

Hrotkó, K. (2000): A cseresznye, meggy és szilva intenzív mủvelési rendszerei. Gyakorlati Agrofórum, 11 (13): 10-14.

Király, K, (2006): Cseresznyefajták intenzív termesztésre való alkalmasságának összehasonlító vizsgálata. Doktori értekezés.

Király K. \& Gonda I. (2004): A fajta szerepe és jelentősége a cseresznye intenzív termesztéstechnológiájában. Debreceni Egyetem Agrártudományi Közlemények, 13: 81-84.

Király, K., Gonda, I. \& Holb, I. (2005): Cseresznyefajták vegetatív és generatív tulajdonságainak összehasonlító vizsgálata. Kertgazdaság, 37 (1): 33-44.

Zahn, F. G. (1986): Intensivierung von Steinobstanlagen durch stärkenbezogene Schnittbehandlung. Erwerbsobstbau, 28: 124-140.

Zahn, F. G. (1990): Die Spindel beim Steinobst. Erwerbsobstbau, 32 (3): 60-66. 